\title{
A viagem do exército de Nabucodonosor em Judite e a sua relevância na literatura judaica helenística
}

\author{
The travel of Nebuchadnezzar's army in 'Judith' and its relevance \\ to the Jewish literature of the Hellenistic Age
}

\section{Victor Passuello*}

\begin{abstract}
Resumo: O Livro de Judite (134-76 A.E.C.), texto apócrifo do Antigo Testamento, escrito em grego koiné, tem atraíd o a atenção de pesquisadores do judaísmo antigo pelo protagonismo da heroína que dá nome ao livro. O livro possui dezesseis capítulos, porém a história de Judite se inicia somente a partir do oitavo capítulo. Essa peculiaridade suscitou debate entre os pesquisadores da obra, pois paira a dúvida sobre a relevância dos capítulos 1 a 7 para a história da heroína. Partindo desta constatação, analisaremos os primeiros capítulos do livro de Judite, que tratam da viagem do exército do rei Nabucodonosor e o propósito desta viagem, tentando identificar se essa parte da obra se enquadra como uma história global fictícia, objetivando críticas aos antigos impérios que dominaram os judeus.
\end{abstract}

\begin{abstract}
The Book of Judith (134-76 B.C.E), which belongs the apocrypha literature of the Old Testament, written in koine Greek, has received a great attention from the scholars of the Second Temple Period due to the role of the heroin Judith in its narrative. The book borrows its title from the heroin Judith and its composed by sixteen chapters. However, the story of Judith begins only in the eighth chapter. This fact raised a lot of questions about the meaning of the first chapters of the book of Judith. Therefore, we will propose that the first half of the book of Judith can be classified, particularly the fictitious travel of Nebuchadnezzar's army, as a critical and fictitious global history of the great ancient empires which subjugated the Jews.
\end{abstract}

\author{
Palavras-chave: \\ Judite. \\ Literatura global. \\ Judeus. \\ Impérios antigos.
}

\author{
Keywords: \\ Judith. \\ Global literature. \\ Jews. \\ Ancient Empires.
}

\footnotetext{
* Professor adjunto de História Antiga e Medieval da Universidade Estadual de Goiás (UEG). Possui doutorado no Departamento de Estudos Clássicos da Universidade de Reading, mestrado pela mesma instituição, mestrado em Historia Antiga pela Universidade Federal do Rio Grande do Sul e graduação em História pela Universidade de Brasília (2002). Membro do grupo de pesquisa Mithra: Laboratório de História Antiga Global, cadastrado no CNPq.
} 


\section{Introdução}

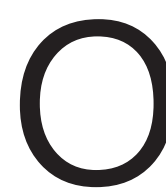

gênero literário de Judite (134-76 A.E.C.) é definido como novela de ficção histórica pela descrição da história de corte que acontece nos capítulos 8 a $16 .{ }^{1}$

Essa parte do livro narra como Judite seduziu e decepou a cabeça de Holofernes, general de Nabucodonosor II (605-562 A.E.C.). Nos primeiros capítulos, de 1 a 7, temos a história dos motivos que levaram Nabucodonosor a convocar o seu general para punir aqueles povos que não tinham oferecido ajuda militar ao rei. Esses motivos são narrados nos dois primeiros capítulos de Judite. Tais questões são analisadas neste artigo.

A primeira metade do Livro de Judite, composta por sete capítulos, para muitos acadêmicos, não se relaciona bem com a sua segunda metade. A principal personagem do livro, a heroína Judite, somente é mencionada a partir do oitavo capítulo. ${ }^{2}$ É a partir do oitavo capítulo que temos os principais elementos que explicam as principais mensagens políticas e teológicas do Livro de Judite.

Muitos pesquisadores que estudam Judite ofereceram diferentes interpretações para explicar como as suas duas metades estão conectadas. Esse problema foi, em parte, resolvido por Lawrence Wills $(2019$, p. 82). Wills argumenta que a primeira metade do Livro de Judite pode ser interpretada como uma macronarrativa que descreve uma visão universalista do mundo conhecido, na época de composição do livro. Essa macronarrativa em Judite é simbolizada pela demonstração de poder de Nabucodonosor e os seus atos de tirania. Os atos e ações de Nabucodonosor, de certo modo, antecipam o desfecho da narrativa de Judite, que é descrito na segunda metade. Para Wills (2019, p. 46), o autor de Judite adotou uma crítica aos grandes impérios antigos, que pode ser caracterizada pela expressão contemporânea decolonial: "universalismo do colonizado". Ou seja, o colonizado, o oprimido, constrói uma crítica ao colonizador de uma maneira global, na qual são demonstradas a importância e a identidade da cultura do colonizado dentro de uma perspectiva global da história. Mas essa narrativa universal é contada do ponto de vista do colonizado e não do colonizador. Não temos em Judite uma metanarrativa tradicional que serve como propaganda dos impérios e dos governantes colonizadores. Ocorre, assim, uma subversão da história da metanarrativa tradicional e histórica

\footnotetext{
${ }^{1}$ A data de composição de Judite é aproximada. Não sabemos a data exata, mas temos a certeza de que o livro foi composto depois de 164 A.E.C. por causa da referência que temos sobre a purificação do Templo que foi feita depois da perseguição de Antíoco Epífano, em 164 A.E.C. Essa referência está no capítulo 4 de Judite. A data final é em referência ao reinado do sumo-sacerdote Alexandre Janneus, segundo rei da dinastia dos Hasmoneus (103-76 A.E.C.). É provável essa data de composição, pois ela corresponde ao auge da dinastia dos Hasmoneus, que conseguiu uma independência, provisória, das potências estrangeiras que dominaram a região da Judeia na época helenística.

2 Para maiores detalhes sobre as discussões acerca da importância dos primeiros capítulos do texto de Judite, veja Johnson (1996, p. 25). O Livro de Judite é composto por 16 capítulos. As referências ao Livro de Judite estão em itálico.
} 
narrada pelos grandes impérios antigos do Oriente Próximo. Essa subversão, em Judite, funciona por meio de uma narrativa que inverte a relação colonizador/colonizado e o conceito de centro/periferia. Essa inversão é típica da literatura bíblica judaica e do judaísmo do Segundo Templo e, ${ }^{3}$ também, encontra eco na literatura decolonial e global contemporânea. ${ }^{4}$ Portanto, para entender qual é a função do deslocamento das tropas do general de Nabucodonosor dentro da narrativa subversiva de Judite, a qual inverte as relações de colonizador/colonizado e de centro/periferia, faz-se necessário descrever, em primeiro lugar, o perfil tirânico de Nabucodonosor construído pelo autor de Judite. É importante notar que uma das características da História Global, em qualquer época, é a conectividade entre os diferentes povos. Os estudos decoloniais e globais sobre a história antiga de Israel e do Segundo Templo constituem uma novidade dentro do campo historiográfico do judaísmo antigo, visto que temos poucas publicações sobre essa temática. ${ }^{5}$

Ao descrevermos o perfil tirânico de Nabucodonosor, em Judite, perceberemos que ele engloba diferentes camadas da história antiga conhecida pelos judeus. Em Judite, cria-se um embate entre o colonizador e o colonizado, cujo desfecho não pode ser entendido somente a partir da micronarrativa na segunda metade do livro. Existem, ao todo, três tipos de conflitos em Judite. O primeiro, entre Nabucodonosor e todos os outros povos do mundo conhecido que se opuseram aos assírios, incluindo os judeus. Esse conflito é descrito na primeira metade do texto. Na segunda metade do texto, na micronarrativa, o conflito continua entre Judite, os judeus da cidade de Betúlia e o general de Nabucodonosor, ${ }^{6}$ Holofernes. O terceiro conflito, que perpassa todo o livro, é entre Nabucodonosor, que se comporta como um deus, e o Deus dos judeus. Temos, então, em Judite, duas macronarrativas e uma micronarrativa. A primeira macronarrativa acontece dentro da história e é descrita pelo conflito entre Nabucodonosor e os povos vassalos

\footnotetext{
${ }^{3}$ As épocas a serem estudadas e destacadas neste artigo começam quando os assírios conquistaram a região de Israel, no século IX A.E.C. e terminam em 63 A.E.C. Nesse lapso de tempo, a região da Judeia e de Israel foram conquistadas pelos assírios, babilônicos, persas e gregos. É a partir dessa época que uma história pós-colonial de Israel e do judaísmo do Segundo Templo, que destaca a relação entre colonizador e colonizado, pode ser construída. Importante ressaltar que o Templo de Jerusalém foi construído por volta de 952 A.E.C. e destruído entre 587/6 A.E.C. Depois foi reconstruído em 515 A.E.C. com autorização dos persas. Foi destruído em definitivo pelos romanos em 70 E.C. O período do Segundo Templo, portanto, vai de 515 A.E.C até 70 E.C. Antes do período do Segundo Templo, o nosso conhecimento sobre a história antiga de Israel depende muito, mas não somente, da história bíblica judaica, como descrito no Antigo Testamento.

${ }^{4}$ Para ler mais textos sobre a relação entre História Global e a literatura decolonial, veja Majundar (2021) e Morales e Silva (2020).

${ }^{5}$ Uma obra recente que aborda a história antiga de Israel do ponto de vista decolonial é a de Baker, Carter e Perdue (2015).

${ }^{6}$ A cidade de Betúlia é uma cidade fictícia que se encontra em uma região real no norte de Israel chamada Samaria. Betúlia pode ser interpretada como um arquétipo que tem um sentido coletivo e que pode significar virgem, casa de Deus ou casa da ascensão (WILLS, 2019, p. 232-233).
} 
da parte ocidental do seu império. A segunda macronarrativa, de caráter estritamente religioso, engloba todo o livro e acontece entre Nabucodonosor e o Deus dos judeus. Essa macronarrativa religiosa fica mais evidente na segunda metade do texto de Judite. E, por último, temos a micronarrativa, isto é, a narrativa de corte em si, comum entre as novelas antigas em geral. Por essas muitas narrativas os estudiosos do livro de Judite lançaram dúvidas sobre como as duas metades devem ser interpretadas. ${ }^{7}$

Existem correspondências tipológicas entre as duas metades do livro, tanto por causa da viagem das tropas de Nabucodonosor, que ocorre no segundo e terceiro capítulos de Judite $(2,12-29.3,1-9)$, como pela questão dos cercos militares às cidades de Ecbatana e Betúlia. ${ }^{8} \mathrm{O}$ deslocamento das tropas de Nabucodonosor para a região da Judeia, foi um fator importante para entender a universalidade da narrativa do texto de Judite e, também, para compreender a natureza da crítica ao rei Nabucodonosor, que o autor de Judite construiu. A universalidade da história que existe no Livro de Judite foi influenciada por uma dupla tradição: uma primeira tradição derivada do Antigo Testamento e dos textos do judaísmo do Segundo Templo. Entre os textos do Segundo Templo, destaque especial pode ser dado aos livros de 1 e 2 Macabeus e ao Livro de Daniel, que, assim como Judite, também foram escritos mais ou menos na mesma época e influenciados de uma forma ou de outra pela Revolta dos Macabeus (160-145 A.E.C.). ${ }^{9}$ Os textos judaicos antigos, em geral, reconheciam os governantes estrangeiros como opressores, pois eles ideologicamente, militarmente e religiosamente se opunham ao Deus dos judeus e aos líderes judeus. Por outro lado, temos uma segunda tradição, que foi da época helenística (séculos III e I A.E.C.). Nessa época existia, entre os autores helenísticos, a pretensão de construções de narrativas universais que serviam como propaganda política dos grandes impérios. Mas também temos narrativas que buscavam redefinir o papel dos povos colonizados dentro do contexto global do mundo conhecido, oikouméne (WILLS, 2021, p. 81-83). Vamos destacar, neste artigo, como o texto de Judite se relaciona com as suas fontes não judaicas que fazem referência ao contexto da Grécia clássica e da época Helenística, com o objetivo de entender como

\footnotetext{
${ }^{7}$ Para uma boa análise sobre os primeiros capítulos de Judite do ponto de vista topográfico e ideológico, veja Otzen (2002, p. 80-93).

${ }^{8}$ Ecbatana era a capital dos Medos. Império que existiu antes dos persas aquemênidas na região do atual Irã. Importante cidade para a história antiga do Oriente Próximo. Foi também a capital de verão dos persas e foi nessa cidade que Alexandre Magno mandou assassinar o seu general, Parmênio, em 330 A.E.C.

${ }^{9}$ A Revolta dos Macabeus foi um acontecimento significativo para a história do judaísmo do Segundo Templo, pois a casa sacerdotal dos Macabeus, nomeada em homenagem ao seu primeiro líder, Judas, o Macabeu (Cabeça de Martelo), além de tomar o poder na Judeia, conseguiu reverter a profanação do Templo de Jerusalém feita por Antíoco Epífano em 164 A.E.C. Em 140 A.E.C., os sucessores de Judas conquistaram a independência do Império Selêucida. Essa independência durou até 63 A.EC. A partir da independência dos Selêucidas, em 140 A.E.C, os Macabeus se intitularam reis e passaram a se chamar Hasmoneus.
} 
esse período influenciou a crítica do autor de Judite aos impérios antigos. As fontes são as Histórias, de Heródoto, e a Crônica de Lindos. ${ }^{10}$

Podemos salientar, como fator contributivo ao estudo do judaísmo do Segundo Templo, que usa a teoria da decolonialidade e da História Global, que a resistência ao colonizador para o autor de Judite não se caracteriza pela construção de uma narrativa alternativa que se opunha de maneira total à cultura do colonizador. Esse tipo de crítica é comum nos textos do Antigo Testamento e no Livro de Daniel, em seu contexto apocalíptico. Nesses textos, os judeus são caracterizados em oposição aos reis e aos povos estrangeiros. O bem contra o mal. O que podemos ver, no Livro de Judite, por outro lado, é a criação de uma metanarrativa na qual os judeus foram capazes de recriar as suas identidades de uma maneira dialógica com a cultura dos grandes impérios que dominaram a Judeia ao longo da história. Os judeus, em Judite, usaram as tradições dos colonizadores (assírios, babilônicos e governantes helenísticos), pelo menos no nível contextual da macronarrativa, com a intenção de reverter a sua condição de colonizados. Os judeus, em Judite, podem ser comparados aos gregos do século $V$ A.E.C., que enfrentaram o Império Persa, conforme é narrado nas Histórias, de Heródoto. Os judeus, em Judite, mantiveram as virtudes que os gregos com o tempo perderam. Usando esta teoria comparativa entre povos colonizados (judeus e gregos), podemos também estabelecer o comparativo entre a tirania do Império Persa e dos reis helenísticos contemporâneos ao autor de Judite. É importante destacar que os persas, na tradição judaica do Antigo Testamento, não são necessariamente considerados tiranos, pois foi Ciro, o Grande (600-530 A.E.C.), quem permitiu o retorno dos judeus do exílio para Jerusalém. ${ }^{11}$

É essa inversão que nos permite interpretar o texto de Judite como uma narrativa que apresenta, dentro de uma perspectiva teórica, semelhanças com a literatura global e decolonial contemporânea, ${ }^{12}$ uma vez que os judeus, em Judite, assumem o perfil dos gregos quando esses não se transformaram ainda em colonizadores. ${ }^{13}$ Além disso, vale destacar que o(a) autor(a) de Judite teve a intenção de criar, também, uma narrativa de ficção histórica, de cunho religioso, que mostrava a superioridade da história universal

\footnotetext{
${ }^{10}$ Deve-se notar que Heródoto era um autor muito popular na época helenística, como observou Murray (1972, p. 200213). A Crônica de Lindos é uma inscrição feita em pedra de mármore datada de 99 A.E.C, mas que contém histórias anteriores que basicamente narram as dedicações feitas em homenagem à deusa Atená de Lindos, cidade localizada em Rodes. A Crônica também contém histórias miraculosas de como a deusa Atenas salvou a cidade dos seus inimigos. É a mais completa inscrição helenística preservada.

${ }^{11}$ Para maiores detalhes sobre como a figura de Ciro, o Grande, é abordada no Antigo Testamento, veja Blenkinsopp (1988).

${ }^{12}$ Para alguns textos literários contemporâneos que adotaram uma perspectiva semelhante do ponto de vista decolonial e global com o texto de Judite acerca da inversão colonizador/colonizado, ver: Bargouthi (2006) e Soueif (2000).

${ }^{13}$ Essa hipótese foi desenvolvida primeiramente por Berthelot (2014, p. 74-75).
} 
dos judeus em relação aos outros povos, incluindo os gregos do século V A.E.C. Essa inversão em Judite pode ser interpretada pelo conceito de glocalização. De acordo com Vassoupoulos (2013, p. 14), o conceito de glocalização, para os antigos, está relacionado com a adaptação e reação das comunidades locais à koíne global. Essa koíne global, no Livro de Judite, é representada pelas referências que existem aos impérios históricos e seus líderes que dominaram a região de Israel e da Judeia ao longo da história e, também, aos textos dos autores gregos que descreveram esses impérios estrangeiros, como no caso de Heródoto e do autor da Crônica de Lindos. Ambos os textos mencionam os reis persas. É praticamente certo que o autor de Judite fez uso de Heródoto e da Crônica de Lindos para compor o perfil de Nabucodonosor e Holofernes e, também, para explicar o desenrolar das ações que os levaram a punir os judeus. Podemos defender essa hipótese porque a história de Judite é, também, uma narrativa histórico-fictícia de cercos militares. Existem dois cercos de cidades em Judite. O cerco à cidade de Ecbatana e a tentativa das tropas de Nabucodonosor em capitular a cidade montanhosa e fictícia de Betúlia. Essas histórias sobre as narrativas de cerco de cidades e sobre a viagem das tropas de Nabucodonosor encontram paralelos nas narrativas gregas antigas, e não somente nos textos das tradições bíblica e do judaísmo do Segundo Templo.

\section{O perfil de Nabucodonosor em Judite e a viagem de suas tropas para a Judeia}

O livro de Judite começa descrevendo Nabucodonosor como um líder que controlava todo o mundo conhecido pelos judeus e os gregos da época helenística. Mas, estranhamente, Nabucodonosor é um líder fictício, pois ele é descrito como o rei dos assírios! (Jt., 1, 1). Em Judite, os reis estrangeiros que dominaram a região de Jerusalém são personagens fictícios, pois eles podem ser interpretados como arquétipos coletivos que entram em oposição ao deus dos judeus. Por outro lado, o autor de Judite não ignora completamente a história, pois a teologia de Judite segue a tradição deuteronônica, na qual a história é sempre o ponto de partida para uma reflexão teológica. ${ }^{14} \mathrm{O}$ que é ausente em Judite, por ser uma ficção histórica, é o ponto de vista autoral. Ao contrário

\footnotetext{
14 O Deuteronômio é um dos cinco livros do Pentateuco, da Torá, "Lei" que dá nome aos prováveis compiladores (deuteronomistas) de parte do Antigo Testamento. Os deuteronomistas foram provavelmente um grupo de sacerdotes que, ao longo da história, deram certa unidade e coesão aos textos do Antigo Testamento, tanto do ponto de vista teológico como histórico. Cada desastre histórico que o povo de Israel sofria era acompanhado por uma reflexão teológica que segue o padrão: pecado, punição e perdão. Em Judite, os judeus não cometeram pecados e, por isso, Deus ajuda Judite a derrotar o exército de Nabucodonosor. Jerusalém, em Judite, não é destruída. Mas Judite não deixa de ser uma história de salvação, pois os judeus dependeram da piedade e virtudes de Judite para garantir a independência e a não profanação de Jerusalém. Para maiores detalhes sobre a relação entre história e teologia em Judite, ver Wills (2019, p. 81-95).
} 
de muitos textos históricos gregos, não temos quase nenhuma informação direta sobre o autor de Judite.

Nabucodonosor parte da sua capital, Nínive, para se opor ao seu mais forte inimigo, Arfarxard, rei dos medos, que reinava a partir da cidade Ecbatana $(J t ., 1,2)$. Existem, assim, em Judite, referências históricas reais, como Nabucodonosor e Ecbatana. No entanto, essas referências são anacrônicas. Provavelmente esse anacronismo aconteceu não porque o autor de Judite não conhecia a história, mas sim, de propósito. Ele queria construir uma narrativa universalista do bem contra o mal, típica das novelas históricas fictícias do judaísmo do Segundo Templo e comum na tradição bíblica do Antigo Testamento. As novelas histórico-fictícias, como gênero literário, surgiram na época helenística e romana a partir do século I E.C. O Livro de Judite, assim, como as novelas históricas e fictícias judaicas, são de uma época anterior (época helenística, séculos III e I A.E.C.). O Livro de Judite está na categoria de novelas apócrifas do Antigo Testamento, assim como Ester e Tobite. ${ }^{15}$ Esses textos judaicos apócrifos podem ser classificados como "narrativas de corte" e antecipam muitas características das novelas gregas e romanas do século I E.C., mas também são diferentes por causa do diálogo que apresentam com a história dos judeus.

A questão do bem contra o mal, do herói contra o vilão, fica mais nítida na segunda parte de Judite (Jt., 8-16). Mas o universalismo de Judite também encontra eco na época da sua composição. Acreditamos que Judite foi escrito por volta do final do segundo século ou começo do primeiro século A.E.C. (WILLS, 2019, p. 16). Nesta época, os gregos já tinham incorporado e entrado em contato com a cultura do Império Persa. Como podemos ver em Heródoto, Ctésias e Xenofonte de Atenas também refletem uma combinação de narrativas históricas orientais com histórias ficcionais de corte. Esse contato efetivo entre gregos e a cultura dos impérios orientais contribuiu para o desenvolvimento de uma escrita da história universal do mundo conhecido que estabelecia um diálogo entre os gregos e os povos do Oriente Próximo antigo e que narrava uma história dos grandes reis e impérios que queriam conquistar todo o mundo conhecido. Essas narrativas universais combinavam o fator político com uma descrição geográfica do mundo conhecido. Essas características podem, também, ser vistas nos primeiros capítulos de Judite.

Em Judite, esse universalismo helenístico convive com outra dimensão maior, de característica religiosa, típica da tradição judaica como se encontra no texto do Antigo Testamento de 2 Reis (18-19) (OTZEN, 2002, p. 74-78). Em 2 Reis, o rei assírio Senaqueribe atacou e destruiu as cidades de Israel e da Judeia, menos Jerusalém, que estava sob

\footnotetext{
${ }^{15}$ Para uma recente e boa discussão sobre os textos apócrifos do Antigo Testamento, veja Wills (2021).
} 
o domínio do rei de Judá, Ezequias. Ezequias, para impedir a destruição de Jerusalém, entregou uma grande quantidade de riquezas que estava no Templo de Jerusalém aorepresentante de Senaqueribe em troca da independência de Jerusalém. Senaqueribe aceitou, mas em uma carta disse a Ezequias que lahweh não seria capaz de defender Jerusalém, pois o poder dos assírios mostrou isso com as conquistas no território de Judá e dos territórios circunvizinhos. Mas Deus atuou, por intermédio do profeta Isaías, em defesa de Jerusalém. Senaqueribe, então, tem as suas tropas mortas pelo anjo de lahweh quando elas estavam prontas para invadir Jerusalém (2 Rs., 19, 36). Em 2 Rs., 18-19, temos uma crise religiosa com os assírios que é resolvida por causa da piedade dos judeus e da súplica do profeta Isaías, que cita um oráculo profético contra os assírios (2 Rs., 19, 20 37). Em Judite, a heroína Judite também, por meio de uma oração, pede a Deus que Ele proteja Betúlia, que é a última cidade, nas montanhas, que dá acesso a Jerusalém (Jt., 9). Em ambos os textos, temos uma narrativa de salvação de Jerusalém contra uma grande potência. Nabucodonosor age como um tirano bíblico em Judite, pois ele irá punir toda a região ocidental do seu império, que se recusou a ajudá-lo durante a campanha contra os medos. A frase "levarei os cativos para os confins da terra" (Jt., 2, 9) nos lembra o que aconteceu com os judeus em Jerusalém quando eles foram derrotados e tornados cativos pelo rei babilônico Nabucodonosor e transportados para Babilônia, em 587 A.E.C., quando o Templo de Jerusalém foi destruído. Holofernes, general de Nabucodonosor, mesmo bem recebido por esses povos:

[...] não deixou de devastar seus santuários e de cortar as suas árvores sagradas. Fora autorizado a exterminar todos os deuses da terra, de maneira que todos os povos adorassem só a Nabucodonosor, e que todas as línguas e todas as tribos o invocassem como deus $(J t, 3,8)$.

Temos, assim, uma visão universalista e teológica da história que coloca lahweh e os judeus contra Nabucodonosor e o seu exército. Mas nunca os reis assírios, babilônicos ou persas demandaram honras divinas dos povos que eles dominaram. Somente Alexandre, o Grande, e os Selêucidas exigiram tais honras. O mais famoso caso na história de profanação de um templo estrangeiro foi realizado por Antíoco IV Epífano que, por volta de 167-164 A.E.C., profanou o Templo de Jerusalém, demandando que os judeus cultuassem Zeus ( Macabeus, 1, 41-56). Temos, assim, uma indicação de que o livro de Judite estabelece um diálogo com o livro de 1 Macabeus e que a época de sua composição foi, provavelmente, depois da Revolta dos Macabeus, pois, em Judite, existe uma referência à restauração e purificação do Templo de Jerusalém que fora feito pelos Macabeus (Jt., 4, 3). 
As semelhanças com a tradição do Antigo Testamento e do judaísmo do Segundo Templo, pelo menos na primeira metade do livro de Judite (capítulos de 1-7), param por aí, pois, na narrativa de Judite, não temos uma intervenção divina direta em nenhum momento. Deus atua pela ação de Judite. Esse fato pode indicar que, em Judite, a descrição dos personagens histórico-ficcionais assume uma grande importância. Assim, o que é surpreendente em Judite é o espaço dedicado à descrição de Nabucodonosor e às suas campanhas contra os seus inimigos. Primeiramente contra Arfaxad e depois contra os povos da parte ocidental do seu império, que se recusaram a apoiá-lo durante o cerco a cidade de Ecbatana, capital do Império Medo e, logo depois, contra os judeus. Claramente, nos três primeiros capítulos, temos uma descrição dessas campanhas que explicam tanto a ascensão de Nabucodonosor, como, também, porque ele poderia ser considerado um tirano. Temos, assim, em Judite, uma história fictícia profunda que apresenta muitas semelhanças com a escrita da história universal que era conhecida na época helenística. Além do passado assírio e babilônico, contado sob o ponto de vista da tradição bíblica, temos, em Judite, uma narrativa relativa ao passado grego sobre o Oriente Antigo, conforme descrito pela historiografia grega e helenística. Esses dois passados se combinam em Judite.

Os primeiros autores que desenvolveram a hipótese de que existem pontos de contato entre Judite e as fontes gregas antigas foram Arnaldo Momigliano (1977, p. 2528) e Moses Hadas (1959, p. 165-169). Depois deles, vieram Mark Stephen Caponigro (1992) e Paul Niskamen (2004, p. 23-25). Esses pesquisadores observaram que o texto de Judite, principalmente em sua primeira metade, apresenta semelhanças com a narrativa de Heródoto e da Crônica de Lindos.

Quem mais desenvolveu a relação que existe entre Judite e Heródoto foi Caponigro (1992). A nossa primeira evidência para tal relação está no fato de que Nabucodonosor, rei da Assíria, é descrito em Judite como dominando tanto a parte ocidental do Oriente Próximo antigo como, também, uma parte oriental que se estendia até o rio Hidaspes, na fronteira com a Índia. A parte oriental do império fictício de Nabucodonosor é descrita em Judite, 1, 5-6. Todos os reinos e povos na parte oriental do império concordaram em mandar tropas para ajudar Nabucodonosor e as suas tropas a conquistarem os medos.

Sabemos que, historicamente, os Impérios Neo-Assírio e Babilônico não chegaram a conquistar a parte oriental do antigo Oriente Próximo, que chegava até a Índia. Portanto, a descrição geográfica do Império Assírio em Judite corresponde, em parte, ao Império Persa, que era muito bem conhecido pelos gregos, e que era um dos representantes de uma visão universal da história. Os persas, de acordo com essa visão universal, eram os sucessores dos assírios, babilônicos e medos. Essa perspectiva de uma história universal 
do mundo conhecido era bastante difundida na época helenística. Assim, essa escala global da história helenística pode ser vista em Jt., 1, 5-10. A parte ocidental do império de Nabucodonosor aparece em Jt. 1, 7-11, conforme podemos ver a seguir:

Nabucodonosor, rei dos assírios, enviou uma mensagem a todos os habitantes da Pérsia, a todos os habitantes da região ocidental, aos habitantes da Cilicia, de Damasco, do Líbano, do Antilíbano, a todos os habitantes do litoral, aos povos do Carmelo, de Galaad, da Alta Galiléia, da grande planície de Esdrelon, a todos que habitavam em Samaria e as suas cidades, aos que habitavam além do Jordão até Jerusalém, em Batana, Quelus, Cades, o rio do Egito, Táfnis e de Mênfis, e a todos os habitantes do Egito, até chegar aos confins da Etiópia. Porém, todos os habitantes da terra menosprezaram a palavra de Nabucodonosor, rei dos assírios, e não se uniram a ele na guerra. Não o temiam. Para eles, era um homem isolado. Mandaram os seus emissários de mãos vazias e menosprezados. Nabucodonosor irritou-se muito com todos esses países. Jurou, por seu trono e seu reino, que se vingaria, de todos os territórios da Cilícia, da Damascena, da Síria, exterminandoos pela espada, bem como dos habitantes de Moab, dos filhos de Amon, de toda a Judéia e de todo o Egito, até chegar às fronteiras dos dois mares (Jt., 1, 7-11).

E logo depois o autor de Judite descreve a campanha de Nabucodonosor contra Arfaxad:

No décimo sétimo ano, combateu, com seu exército, contra o rei Arfaxad. Venceu-o neste combate e rechaçou todo o exército de Arfaxad, toda a sua cavalaria, todos os seus carros. Assenhorou-se de suas cidades até chagar a Ecbatana. Apoderouse das torres, devastou as suas praças, fez do seu adorno motivo de humilhação. Depois prendeu Arfaxad nas montanhas de Ragau, atravessou-o com suas lanças e o exterminou para sempre. Em seguida, ele e toda a sua tropa, uma multidão inumerável de guerreiros, retornaram. Então, despreocupados, ele e o seu exército se banquetearam por cento e vinte dias (Jt., 1-13-16).

Na primeira passagem acima, temos uma descrição detalhada de uma grande variedade de nações e povos. Semelhantes listas de conquistas de várias nações pelos governantes do antigo Oriente Próximo existem em diversas fontes antigas, como disse Wills (2019, p. 46). Seja na narrativa bíblica, como na campanha de Abraão em Genesis 14 ou em 1 Samuel $(14,47)$. No entanto, listas semelhantes também são encontradas na literatura grega antiga, como em Diodoro da Sícilia (Bibliotheca Historica, II, 2, 3) ou no Romance de Alexandre (recensão grega), com o rei Dario assumindo um papel semelhante ao de Nabucodonosor: "Dario, o rei dos reis, o grande deus Dario, lorde de todas as nações [...] escreveu para todas as nações vassalas, requisitando delas juntar a ele e as suas tropas" (Pseudo-Calístenes, Historia Alexandri Magni, I, 40-42). ${ }^{16}$ Wills (2019, p. 178180) ainda diz que essa oposição das nações vassalas de Nabucodonosor pode refletir o

\footnotetext{
${ }^{16}$ Seguimos aqui a tradução de Stoneman (1991).
} 
contexto do século Il ou da metade do século I A.E.C., na época dos Selêucidas e Ptolomeus, uma vez que existiu um vácuo de poder na Coele-Síria. Os nabateus e as cidades-Estados de Tiro, Sídon e Ascalão, além dos Hasmoneus (i.e., a dinastia sucessora dos Macabeus), conseguiram, durante certo tempo, alguma independência dos governantes helenísticos. O efeito da lista de nações de Jt., 1, 7-10 é a criação de uma universalidade, que extrapola a história antiga de Israel e a conecta a uma história de "pretensão universal", mostrando como a história do colonizador e do colonizado andam juntas. Outro fato importante que mostra essa preocupação por parte do colonizado em criar uma narrativa universal está ligada à reação das nações e povos vassalos contra as ordens de Nabucodonosor, como na última parte da primeira passagem citada acima: "Mandaram de volta os seus emissários de mãos vazias e menosprezados" (Jt., 1, 11).

Essa passagem nos lembra o contexto de Heródoto nas suas Histórias, quando, depois de ter subjugado os gregos da Jônia, Dario I, rei da Pérsia, em campanha na Grécia continental, demanda o tributo simbólico de "terra e água" dos gregos. A expressão "terra e água" era uma marca de submissão que os persas demandavam dos povos que eram seus vassalos. Em Heródoto (Historiae, VII, 132, 133), todos os povos da Grécia continental aceitam a demanda dos persas, menos os atenienses e espartamos, que jogam os emissários dos persas em um fosso e numa cisterna respectivamente. Essa comparação pode ser uma simples coincidência, mas não é, pois, logo depois, no capítulo 2, o autor de Judite usa a famosa expressão "terra e água" que sai da boca do próprio Nabucodonosor. Nabucodonosor, em Judite, está demandado vingança pelo fato de que os povos vassalos da parte ocidental do seu império recusaram-se a ajudá-lo contra os medos: "Intimá-lo-ás a que preparem terra e água porque, no meu furor, sairei contra eles" $(J t ., 2,7)$.

Já temos, portanto, um primeiro indício de que Nabucodonosor se comporta como o rei persa Dario I. Já os povos rebeldes, os povos ocidentais, incluindo os judeus, se comportam como os atenienses e os espartanos. Essa comparação reforça a nossa hipótese sobre o conceito teórico do "universalismo do colonizado", como explicamos na introdução.

Segundo Caponigro (1992, p. 50), somente a referência à expressão 'terra e água' não indica que o autor de Judite tenha lido e usado Heródoto como fonte, uma vez que essa referência pode ter saído diretamente do vocabulário diplomático persa. Precisamos de mais referências. E elas existem, conforme Caponigro (1992. p. 51-52). Em Jt., 2, 1-3, existe um problema de interpretação que pode nos remeter ao texto de Heródoto:

No décimo oitavo ano, no vigésimo segundo dia do primeiro mês, no palácio de Nabucodonosor, rei dos assírios, falou-se em vingança contra toda a terra, conforme ele dissera. Ele convocou todos os seus ajudantes de campo e todos 
os seus conselheiros e fez com eles uma reunião secreta. Por sua própria boca, ultimou o plano de arrasar a terra. Decidiram, então, exterminar todos os que não haviam atendido ao seu apelo.

De acordo com Caponigro (1992), a passagem acima apresenta semelhanças com a passagem na qual o rei Persa, Xerxes, de acordo com Heródoto (Hist., VII, 5-11), está em uma conferência para decidir se os persas irão mesmo invadir a Grécia. Nessa conferência, Mardônio, general persa, faz um discurso favorável à guerra contra os gregos. A correspondência entre Judite e Heródoto, para Caponigro (1992), pode estar no fato de que o discurso no palácio de Nabucodonosor não vem inicialmente da boca dele: "falou-se em vingança contra toda terra". Isso é uma inconsistência, pois, no capítulo anterior (Jt., 1), a intenção de punir os povos na margem ocidental de seu império fora feito pessoalmente por Nabucodonosor. Assim, alguém o lembrou de sua promessa. Semelhante fato acontece em Heródoto, quando Mardónio convence Xerxes e os seus aliados na corte a iniciar uma guerra contra os gregos. Essa seria a alternativa mais sensata que dá sentido à narrativa de Judite (CAPONIGRO, 1992, p. 52). Para Caponigro (1992), o autor de Judite fez uma adaptação da passagem de Heródoto (Hist., VII, 5-11), comprimindo as duas partes em uma (Hist., VII, 5-7; VII, 8-11). Na primeira parte de Heródoto, é narrado como Mardônio convenceu Xerxes a iniciar a campanha contra os gregos. Na segunda parte da passagem, é relatado o segundo evento, que é a conferência em si. Não bastasse isso, Caponigro (1992, p. 52) fala que, no texto grego de Judite 2, 2, temos três usos de kai (e) como conectivo. Tal expressão não é comum em textos semíticos traduzidos para o grego, como no caso de Judite.

\section{Betúlia, Herodóto e a Crônica de Lindos}

O uso de Heródoto e da Crônica de Lindos pelo autor de Judite pode ainda ser visto no caso de Betúlia, depois da narrativa da viagem do exército de Nabucodonosor, liderado por Holofernes, para punir os povos que viviam na parte ocidental do seu império. Essa campanha é narrada nos capítulos 2 e 3 . Um fato curioso acontece nessa parte da narrativa de Judite, pois as tropas assírias entraram, estranhamente, pelo norte de Israel e acamparam na fronteira da Judeia, entre Geba e Citopólis, região perto da Samaria (Jt., 3, 9). Essa não era a rota normal. A intenção dessa campanha era punir os judeus em Jerusalém, o único, entre os povos da parte ocidental, que se recusou a receber as tropas de Holofernes e abrir as suas fronteiras. A reação dos judeus foi de alerta. Eles se prepararam para a batalha, uma vez que, saindo recentemente do cativeiro da Babilônia, eles tinham purificado o templo da profanação que fora ordenado por Antíoco 
IV Epífano, em 167 A.E.C. ${ }^{17}$ Por essa razão, os judeus não iriam se render aos assírios. Como o autor de Judite queria construir uma narrativa independente do poder central dos sumos sacerdotes de Jerusalém, a cidade de Betúlia foi inserida na narrativa. Betúlia, por estar localizada na região da Samaria, também representaria o elo mais fraco dos judeus, pois a região do norte de Israel foi a primeira, na história, a ser conquistada pelos impérios estrangeiros. Betúlia também funciona como um arquétipo, pois ela representa todos os judeus na narrativa de Judite. O nome Betúlia pode ser traduzido do hebraico como "virgem" ou "casa de Deus". Betúlia é a cidade de Judite. Judite, assim, é a heroína, mais improvável que iria salvar todos os judeus, uma vez que ela vinha de uma cidade distante do centro, que era Jerusalém.

O autor de Judite, a partir do capítulo 4, concentra toda a sua atenção no cerco de Betúlia por parte das tropas de Holofernes. Para chegar a Jerusalém, os assírios teriam que passar pela região montanhosa em que está localizada Betúlia. Isso é estranho, como dissemos acima, pois o caminho que passava pelo norte de Israel nunca foi usado historicamente para se conquistar Jerusalém (CAPONIGRO, 1992, p. 54). Essa invenção de Betúlia serviu aos interesses do autor de Judite, que queria, a partir do cerco a essa cidade, criar uma micronarrativa que iria se concentrar na relação entre os dois protagonistas da segunda parte de Judite: Judite e Holofernes. A partir desse cerco e da demora de ele se concretizar, o autor de Judite, como disse Caponigro (1992, p. 54-55), tem tempo para desenvolver sua narrativa de corte que se passa entre Judite e Holofernes, na tenda de Holofernes, que está localizada no acampamento dos assírios. Conforme é narrado em Judite, a heroína Judite tem somente cinco dias para salvar os judeus em Betúlia, pois esse é o tempo restante que os judeus de Betúlia dispõem da água que está armazenada nas suas cisternas. Holofernes, em vez de invadir Betúlia, decidiu cercar a cidade e deixá-la sem água (Jt., 7, 11-15). Semelhante estratégia adotada por Holofernes pode também ser vista na Crônica de Lindos, que, assim como o livro de Judite, também é uma história de salvação de uma cidade que está cercada (epifania). Na Crônica de Lindos, a cidade de Lindos, na ilha de Rodes, é cercada pelas tropas persas do rei Dario e, também, está com pouca água em seus reservatórios. Mas, graças à intervenção da deusa padroeira da cidade, Atená de Lindos, a chuva aparece

\footnotetext{
17 Importante destacar que a profanação de Jerusalém por Antíoco Epífano marcou profundamente o autor de Judite. O livro de Judite, assim, pode ser interpretado, de certo modo, como uma história de salvação inspirada pelos feitos dos Macabeus conforme eles são narrados nos livros de 1 e 2 Macabeus. Existem em Judite muitas referências contra a destruição de Jerusalém cometidas por Antíoco Epífano. Essas referências estão ligadas ao tema da virgindade e vingança de Judite contra os reis que destruíram Jerusalém ao longo da História. Nesse sentido, Judite representa metaforicamente todos os judeus, assim, como Nabucodonosor representa todos os reis estrangeiros que destruíram Jerusalém ao longo da história. O tema da vingança coletiva em Judite pode ser visto mais claramente no capítulo 9.
} 
na cidade para salvar os gregos. O que faz Dátis, general de Dario, desistir do cerco (Lindian Temple Chronicle, XLII, D; HIGBIE, 2003, p. 43-45).

Assim, a cidade de Betúlia, que está em um vale entre as montanhas, representa o último bastião de defesa de toda a região da Judeia. Esse fato da narrativa de Judite, provavelmente, foi inspirado na narrativa de Heródoto sobre a batalha das Termópilas (Hist., VII 176), como diz Caponigro (1992, p. 53). Mas a referência de Judite à narrativa de Heródoto em relação à batalha das Termópilas para por aí.

É importante dizer que as referências que Judite faz ao texto de Heródoto e da Crônica de Lindos são adaptadas para os seus propósitos, por isso elas são pontuais. Assim, elas são comprimidas e não usadas literalmente e, em muitos casos, elas são referências indiretas. Isto é, elas devem ser interpretadas pelo contexto da narrativa, mas elas são constantes. Tudo isso faz parte dos propósitos de Judite na construção de uma narrativa de cunho universalista e global, na qual diferentes tradições históricas são misturadas e combinadas. Nabucodonosor representa uma mistura de todos os reis do Oriente Próximo que entraram em contato com os judeus através da história. Entre esses líderes podemos, também, incluir os reis persas. Só que esses reis persas não são os reis persas do Antigo Testamento, mas os reis persas de Heródoto.

\section{A inversão da história: centro e periferia}

Continuando a nossa interpretação do Livro de Judite, podemos ver que, logo depois da decisão em fazer uma campanha contra os povos ocidentais, Nabucodonosor convoca o seu principal general, Holofernes, para liderar essa campanha (Jt., 2, 9-13). Nabucodonosor diz que Holofernes deve trazer todos os povos rebeldes para o cativeiro e colocá-los nos confins da terra (Jt., 2, 9). Repetindo, assim, a história do cativeiro dos judeus na Babilônia. No entanto, dessa vez isso não vai acontecer, pois os judeus, pelo intermédio da heroína Judite, serão capazes de ganhar a guerra.

Judite, a heroína, entra em ação a partir do capítulo 8. No final desse capítulo ela explica por qual motivo os judeus da cidade fictícia de Betúlia não devem temer as tropas de Holofernes, que já atravessaram todo o império de Nabucodonosor e estão acampadas no sopé da montanha em que está localizada a cidade de Betúlia. Judite, já na segunda metade do livro, diz que os judeus, que estão apavorados com a chegada das tropas de Holofernes e estão pensando em se render, não devem se preocupar com os assírios, pois: 
[...] não houve nas nossas gerações, nem há nos dias de hoje nenhuma de nossas tribos ou famílias, nenhum dos povos ou cidades que adorem deuses feitos pelas mãos do homem, como aconteceu outrora [...]. Nós, na verdade, não conhecemos outro Deus além dele. Por isso, confiamos que não nos olhará com desdém, nem se afastará da nossa raça (Jt., 8, 18-20).

Essa passagem é importante porque ela antecipa a vitória dos judeus por intermédio de Judite e, também, explica a inversão da história que acontece em Judite dentro do contexto de centro e periferia. Devemos lembrar que a inversão da história na qual a periferia prevalece sobre o centro é uma característica muito comum da literatura decolonial global contemporânea. No capítulo 3 de Judite, temos a descrição da viagem das tropas de Nabucodonosor de Nínive, capital do seu império, para Betúlia. Nessa viagem há um grande deslocamento das tropas pelo império, que passam por muitas regiões trazendo terror para as cidades e localidades que se opuseram aos assírios. Existe uma detalhada descrição topográfica. Todavia, segundo Otzen (2002), essa topografia, na maioria dos casos, é fictícia. Otzen (2002, p. 90) afirma ainda que a principal função da viagem das tropas assírias e da descrição topográfica dessa viagem é ideológica, uma batalha cósmica entre o bem e o mal. Concordamos, em parte, com essa interpretação, pois o aspecto cósmico não aparece nitidamente na primeira metade do livro de Judite, estamos ainda em contexto terreno e humano. Portanto, na descrição do deslocamento das tropas assírias, lideradas por Holofernes, o autor de Judite parece seguir a macronarrativa da propaganda dos impérios assírios e babilônicos, que é a seguinte: viagem de punição aos estados e povos vassalos e, uma outra viagem, na qual os líderes desses povos são levados em cativeiro para as distantes cidades do império. Essa dispersão era feita com a finalidade de punição, mas também com a intenção de que as elites desses povos subjugados e revoltosos fossem integradas à cultura dos conquistadores. Em Judite, essa narrativa é invertida, pois o cerco à cidade de Betúlia é frustrado. Judite seduz Holofernes na sua tenda e decepa a sua cabeça com um facão (Jt., 13, 7-8). Logo depois, ela leva a cabeça de Holofernes para a cidade de Betúlia e pede para os seus habitantes deixarem a sua cabeça exposta no parapeito da muralha da cidade (Jt., 14, 1). Com a morte de Holofernes, as tropas assírias debandam e, em terror, fogem do acampamento. Muitos são perseguidos pelo exército de Israel e o acampamento de Holofernes é saqueado (Jt., 15, 1-3).

Existe, assim, uma inversão da história na narrativa fictícia de Judite. A dispersão ocorre entre os assírios e não entre os judeus. Os judeus conseguem vencer o inimigo. Desse modo, a periferia ganhou a guerra fictícia que é narrada no livro de Judite. Essa inversão só fica clara nos capítulos finais de Judite. Mas podemos ver uma antecipação 
dessa vitória e elementos dessa inversão já nos capítulos iniciais, pois os judeus se comportam como os atenienses e os espartanos do século V A.E.C., que expulsaram os persas dos seus territórios. Nabucodonosor em Judite, por outro lado, se parece com os reis persas, conforme descrito nas Histórias, de Heródoto.

\title{
A crítica aos atenienses
}

Existe, também no texto de Judite, certa crítica aos atenienses do século $\vee$ A.E.C. De acordo com Heródoto, os atenienses também tiveram certa culpa na guerra que eles desenvolveram com os persas. Esse fato não passou despercebido pelo autor de Judite. Isso pode indicar que, para o autor de Judite, os gregos, em geral, não eram totalmente confiáveis. Interpretamos, assim, que o autor de Judite construiu uma narrativa de cunho universalista que ressaltava também a superioridade dos judeus em comparação com os gregos do século V A.E.C. A evidência para essa interpretação acerca dos atenienses, por parte do autor de Judite está no capítulo 3:

\begin{abstract}
Enviaram a ele mensageiros com a palavra de paz, dizendo: 'Somos servidores do grande rei Nabucodonosor, prostramo-nos diante de ti (estamos a sua disposição) serve-te de nós conforme for do teu agrado [...]'. Os habitantes apresentaram-se, a Holofernes e falaram nestes termos. Ele com o seu exército, desceu para a costa e estabeleceu guarnições nas cidades fortificadas [...]. Mas ele não deixou de devastar seus santuários e de cortar as suas árvores sagradas (Jt., 3, 1-8).
\end{abstract}

Dois fatos importantes acontecem nessas passagens. A primeira é que as nações da parte ocidental do império de Nabucodonosor, antes rebeldes, agora, com a chegada das tropas lideradas por Holofernes, se rendem aceitando suas posições de vassalos, "prostramo-nos diante de ti". Essa é a tradução da Bíblia de Jerusalém usada neste artigo como o texto principal de Judite. Mas, também, colocamos em parênteses a tradução da NETS, que é a tradução mais próxima do sentido grego original de Judite. De acordo com essa segunda tradução, o ato de submissão das nações ocidentais conquistadas por Holofernes não significa bem se ajoelhar, mas estamos ao seu lado (estamos à sua disposição). ${ }^{18}$ De qualquer maneira, o sentido de submissão e rendição está claro. Essa submissão dos povos vassalos dos assírios lembra o comportamento dos povos e das cidades gregas que se renderam aos persas. Essas nações ajoelharam-se para os persas (proskýnesis, ajoelhar-se), conforme podemos ver em Heródoto (Hist., VII, 13, 133-136). Para os gregos, como os espartanos e atenienses, o ato de ajoelhar-se era um sinal de

${ }^{18}$ NETS é a abreviação de A New English Translation of the Septuagint (2007). O livro de Judite foi preservado somente em grego e se encontra entre os textos que estão na Septuaginta. 
escravidão e rendição. Fato, esse, que os atenienses e espartanos não aceitavam. O ato de ajoelhar-se, entre os gregos, só era permitido para os deuses. Junto com a expressão "terra e água", o ato de ajoelhar-se era também um ato de submissão aos persas. Os judeus em Judite, assim como os espartamos e atenienses, recusaram tais atos de submissão. A outra questão importante refere-se à atitude de Holofernes em punir os povos que foram conquistados por suas tropas. Essa punição está representada em Judite pelo ato de destruição de santuários e das árvores sagradas que se encontram nesses locais sagrados. Aqui temos, também, uma referência ao texto de Heródoto. Essa referência não foi notada por Caponigro (1992). A referência está em Heródoto (Hist., VII, 8), quando o rei persa Xerxes queria punir os atenienses, pois eles devastaram os santuários e as árvores sagradas da cidade de Sárdis, na Lídia, na época do seu pai, Dario. Assim, podese perceber que o autor de Judite, no capítulo 3, fez, também, uma crítica aos atenienses do século V A.E.C. Essa crítica não pode passar despercebida. E pode significar que os judeus, de acordo com o autor de Judite, eram um povo exemplar, virtuoso, tanto na luta pela independência das suas tradições, como no respeito que tinham pelas tradições religiosas dos outros povos.

\section{Considerações finais}

Demonstramos que é possível usar a concepção heurística de crítica global contemporânea para interpretar a macronarrativa do texto de Judite, que está relacionada com a tentativa de Nabucodonosor conquistar o mundo conhecido da época. Nabucodonosor se comporta como o rei Xerxes, conforme ele é descrito nas Histórias, de Heródoto. Observamos que o autor de Judite glocalizou o rei Nabucodonosor. Conclui-se, também, que a viagem das tropas de Nabucodonosor ajudou a conectar as duas metades do livro e que ela também deve ser interpretada dentro de uma perspectiva decolonial, na qual existe uma inversão entre o centro e a periferia. O uso constante de Heródoto, na época do Segundo Templo, mostrou que os judeus estavam em um constante diálogo com os gregos e, também, em busca de uma redefinição das suas identidades na época helenística. Época, essa, que provocou a criação de uma limitada história global antiga do mundo conhecido, na qual o passado era reelaborado para atender às demandas do presente, principalmente entre os povos que sofreram com as conquistas de Alexandre e dos seus sucessores (diádocos). 


\section{Referências}

\section{Documentação textual}

PIETERSMA, A.; WRIGHT, B. G. (ed.). A New English Translation of the Septuagint (NETS). New York/Oxford: Oxford University Press, 2007.

ANDERSON, A. F.; GORGULHO, G. da S.; STORNIOLO, I. (ed.). Bíblia de Jerusalém. São Paulo: Paulus, 1987.

DIODORUS SICULUS. Library of history. Edited and translated by C. H. Oldfather, C. T.

Sherman, C. Bradford Welles, R. M. Greer and F. R. Walton. Harvard: Harvard University Press, 1933-1967. 12 v.

HIGBIE, C. The Lyndian Chronicle and the creation of their past. Oxford: Oxford University Press, 2013.

HERODOTUS OF HALICARNASSUS. The histories. Edited and translated by A. D. Godley. Cambridge: Harvard University Press, 1920-1925. 4 v.

STONEMAN, R. The Greek romance of Alexander. London: Penguin, 1991.

\section{Obras de apoio}

BAKER, C. A.; CARTER, W.; PERDUE, L. G. Israel and Empire: a postcolonial History of Israel and Early Judaism. New York: Bloomsbury, 2015.

BARGOUTHI, M. Eu vi Ramallah. Rio de Janeiro: Casa da Palavra, 2006.

BERTHELOT, K. Hellenization and Jewish identity in the Deuterocanonical Literature: a response to Ben Wright. In: XERAVITZ, G. G.; ZSENGELLÉR, J.; SZABÓ, X. (ed.). Canonicity, setting, wisdom in the Deuterocanonicals: papers of the jubilee meeting of the International Conference on the Deuterocanonical Books. Berlin: De Gruyter, 2014, p. 74-75.

BLENKINSOPP, J. Ezra-Nehemiah: a commentary. Philadelphia: The Westiminster Press, 1988.

CAPONIGRO, M. S. Judith, holding the Tale of Herodotus. In: VANDERKAM, J. C. (ed.). "No one spoke ill of her": essays on Judith. Atlanta: SBL, 1992, p. 47-60.

HADAS, M. Hellenistic culture: fusion and diffusion. New York: W. W. Norton \& Company, 1959.

JONHSON, S. R. Historical fictions and Hellenistic Jewish identity. Berkeley: University of California Press, 1996. 
MAJUNDAR, N. The world in a grain of sand: postcolonial literature and radical universalism. London: Verso, 2021.

MOMIGLIANO, A. Essays in ancient and modern historiography. Middletown: Wesleyan University Press, 1977.

MORALES. F. A.; SILVA, U. G. História Antiga e História Global: afluentes e confluências. Revista Brasileira de História, v. 40, n. 83, p. 126-150, 2020.

MURRAY, O. Herodotus and Hellenistic Culture. The Classical Quartely, v. 22, n. 2, p. 200213, 1972.

NISKAMEN, P. V. The human and the divine in History. London: T\&T Clark, 2004.

OTZEN, B. Tobit and Judith. London: Sheffield Academic Press, 2002.

SOUEIF, A. In the eye of the sun. London: Pantheon Books, 2000.

WILLS, L. M. Judith: a commentary (Hermeneia). Minneapolis: Fortress Press, 2019.

WILLS, L. M. Introduction to the Apocrypha: Jewish books in Christian Bibles. New Haven: Yale University Press, 2021.

VLASSOPOULOS, K. Greeks and Barbarians. Oxford: Oxford University Press, 2013. 